\title{
Management Strategy for Quality Improvement of Madrasah-Based Education in North Sulawesi
}

\author{
Nurhayati $^{1^{*}}$, J.A.M. Rawis ${ }^{2}$, H.N. Tambingon ${ }^{3}$, Jeffry.S.J. Lengkong ${ }^{4}$ \\ ${ }^{1}$ Institut Agama Islam Negeri Manado \\ 2,3,4 Program Pascasarjana Universitas Negeri Manado \\ * Corresponding author: \\ Email: nurhayati.sahibe@,iain-manado.ac.id
}

\begin{abstract}
.
This research focuses on the management of madrasa-based education quality improvement strategies in North Sulawesi. The research was conducted at three madrasah, namely Manado State Madrasah Tsanawiyah (MTs Negeri 1 Manado), Bitung State Madrasah Tsanawiyah (MTs Negeri 1 Bitung) and Kotamobagu State Madrasah Tsanawiyah (MTs Negeri 1 Kotamobagu). The research method used is descriptive qualitative with data collection techniques through observation, interviews, and documentation. The results of this study indicate that the Strategic Planning for improving the quality of madrasa-based education at MTs Negeri 1 Manado, MTs Negeri 1 Bitung and MTs Negeri 1 Kotamobagu City is carried out by involving all components of madrasas and stakeholders in an effort to improve the quality of madrasa education while still referring to Islamic values as a characteristic of madrasas. The implementation of the strategy to improve the quality of madrasa-based education is realized by implementing work programs in planning for improving the quality of madrasas such as education and training/training, workshops, seminars, organized by the government, ministries and universities. The impact of implementing strategies to improve the quality of education in madrasas can be seen from a number of indicators such as increased learning outcomes, which can be seen from academic and non-academic achievements achieved by students in various activities, and competitions.
\end{abstract}

Keywords: management strategy, quality, madrasah, planning, evaluating.

\section{INTRODUCTION}

The process of improving the quality of education is the first step to realize the quality of education and the welfare and prosperity of a nation. According to Suryana (2017:2), the development of national education in Indonesia is still faced with various challenges in improving the quality of education. The implementation of education by educational institutions is expected to be able to apply the meaning of education, namely education is a conscious and planned effort to create a learning atmosphere and learning process so that students actively develop their potential to have religious spiritual strength, self-control, personality, intelligence, morals noble character, as well as the skills needed for himself, society, nation and state (Law of the Republic of Indonesia No. 20 of 2003). The implementation of education by educational institutions is at least able to achieve the meaning of education above. Seeing the current situation and conditions, it is not easy to achieve all the components listed in the National Education System Law, but if it is accompanied by maximum intention and effort by formal and non-formal institutions, it is hoped that the educational outputs and outcomes that have been aspired will be realized. In its implementation, the government issued Government Regulation No. 32 of 2013 concerning national education standards. In the explanation of the Government regulation, it is stated that the vision of national education is to realize the education system as a strong and authoritative social institution to empower all Indonesian citizens, to develop into quality human beings, so that they are able to proactively respond to the challenges of an ever-changing era.After the reformation, the regional autonomy paradigm became the basic paradigm of determination in all joints of state regulations (Usman, 2006:572).

In line with regional autonomy, the government is determined to implement the decentralization of 
education which overlaps with the empowerment of schools/madrasahs at all levels of education. Since the implementation of regional autonomy on January 1, 2001, the Ministry of National Education has changed the orientation of school/madrasah management which was previously centrally based (SBM/M) to School/Madrasah-Based Management (Usman, 2006:573). It aims to improve all school/madrasah performance in effectiveness, quality/quality, efficient innovation, relevance and equity as well as access to education (Mulyasa, 2002:11).Aziz (2015: 70) states that the low quality of madrasa education is caused by the implementation of education that does not pay attention to the quality aspects of the learning process. The concept of quality improvement in education is managed through the Madrasah-Based Quality Improvement Management (MPM-BM) process which is the embryo of school/madrasah-based management. In the concept of improving the quality of madrasas, it should be programmed and planned and carried out independently by madrasas based on the needs of the madrasa itself to achieve goals. As stated by Rawis (2009:130) that planning is an important activity in compiling and determining a series of activity plans. The plan is the basis and reference in implementing the program to achieve the objectives set also mentions the urgency of planning so that any organization needs to have an activity plan and work plan (Lengkong, 2019:21; Ismail, Pawero, \& Umar, 2021).According to Rusman (2009:74) quality education refers to the educational process and educational outcomes.The quality education process involves various inputs, such as teaching materials, methodologies, infrastructure, other resources and the creation of a conducive atmosphere. Meanwhile, quality in the context of educational outcomes/outputs refers to the achievements achieved by the madrasa in any given period of time, whether at the end of the semester, every year, two years or five years, even ten years.Educational institutions in Indonesia are a place for improving human resources, having many varieties, including madrasas.

According to Sutrisno (2005:73) the purpose of establishing a madrasa is essentially to collect the advantages that exist in Islamic boarding schools and public schools, as well as in one institution, namely madrasas. As is well known, pesantren do have advantages in Islamic religious sciences and public schools have advantages in general sciences. That is why madrasas are expected to be able to synergize the two advantages above into one advantage (quality standard) equal to or even higher than public schools. This requires good strategic management in improving the quality of madrasas, especially madrasas in North Sulawesi. Rotty, et al. (2017:52) mentions the need for support and involvement of all parties in overcoming educational problems in North Sulawesi. As stated by Ricard L. Daft (2010:212) he stated that strategic management begins with an evaluation of the current mission, goals and strategies. Tambingon (2018: 358) says that evaluation is an activity to find out what is being done and determine the necessary policies. Thus, madrasas need to carry out good strategic management in an effort to improve the quality of education in North Sulawesi.According to the results of a preliminary study at the three Madrasah Tsanawiyah in North Sulawesi, the implementation of improving the quality of education in Manado State Madrasah Tsanawiyah (MTs Negeri 1 Manado), Bitung State Madrasah Tsanawiyah (MTs Negeri 1 Bitung) and Kotamobagu State Madrasah Tsanawiyah (MTs Negeri 1 Kotamobagu), such as: a ) learning processes that are not quality oriented, b) educational facilities and infrastructure that are not fully in accordance with national education standards, and c) student achievements that have not been outstanding and have not been seen nationally. This study aims to describe and analyze the planning, implementation and evaluation of strategies for improving the quality of madrasah-based education at MTs Negeri 1 Manado, MTs Negeri 1 Bitung and MTs Negeri 1 Kotamobagu.

\section{METHODS}

This study uses a multi-case study approach as a basis for describing a particular situation that is collected through observation, participant interviews, and documentation studies, by comparing various matters relating to the management of madrasa-based education quality improvement strategies in North Sulawesi, namely Manado State Madrasah Tsanawiyah (MTs Negeri 1), Bitung State Madrasah Tsanawiyah (MTs Negeri 
1 Bitung) and Kotamobagu State Madrasah Tsanawiyah (MTs Negeri 1 Kotamobagu).The research process starts from a broad and in-depth exploration and then continues with more focused data collection and analysis activities until finally a comprehensive conclusion is obtained about the management of madrasa-based education quality improvement strategies.

This multi-case study design is intended to describe the similarities and differences between cases related to the management of madrasa-based education quality improvement strategies. This multi-case design was developed in two stages, namely the single-case analysis stage (per school), and the cross-case analysis stage, namely by combining and comparing the three cases. Therefore, the suitable research method is the constant comparative method. This method emphasizes more on data collection and analysis techniques that can take place simultaneously. The steps taken were to collect data with a focus category on State Madrasah Tsanawiyah (MTs), then analyzed to find an implementable concept related to the management of madrasabased education quality improvement strategies.

\section{RESULT AND DISCUSSION}

Based on the exposure of the research data, it can be described the research findings related to the strategy of improving the quality of madrasa-based education in the research location.

\section{Strategy for Improving the Quality of Education at MTs Negeri 1 Manado}

In accordance with the research data described previously, there are several research findings related to quality improvement strategies in Manado State Madrasah Tsanawiyah (MTs Negeri 1 Manado).

a) Planning Strategy for Madrasah Quality Improvement at MTs Negeri 1 Manado

The planning strategy is carried out through meeting and deliberation activities with educators and education personnel as well as stakeholders. The formulation of the vision and mission of Madrasah Tsanawiyah (MTs) Negeri 1 Manado is carried out by involving all components of the madrasa, starting from the madrasa head, teacher council, OSIS management, madrasa committee and stakeholders providing advice and considerations and being a liaison for the formulation of the vision and mission of Madrasah Tsanawiyah (MTs) State 1 Manado. Likewise, madrasa curriculum development is designed and planned based on the reference to the national education curriculum and the madrasa curriculum is adapted to local conditions.

Planning to improve the quality of Madrasah education at MTs Negeri 1 Manado is carried out by involving madrasa components and stakeholders. Starting from the process of formulating the vision, mission, and goals of the madrasa. Vision, mission are the ideals to be achieved, it is very necessary for all components of the madrasa to know and understand well, the vision, mission to motivate the institution and the community / stakeholders in an effort to improve the quality of madrasa education through the stages according to the program that has been set.

b) Strategy for implementing Madrasah Quality Improvement at MTs Negeri 1 Manado

The implementation of improving the quality of education can be seen in the development of the madrasa curriculum. The learning process at Madrasah Tsanawiyah Negeri 1 Manado is carried out using an integrated curriculum, meaning that all fields of study are designed to integrate spiritual values and moral nobility so that students become a generation of knowledge, faith, and dignity. In other words, students who have faith and piety and are knowledgeable and master technology. Thus, Madrasah Tsanawiyah (MTs) Negeri 1 Manado carries out quality improvement based on the vision and mission of the madrasa that has been determined together with a religious and religious basis. Implementation of madrasa-based quality improvement by maintaining the originality of madrasa values.

\section{c) Impact of Madrasah Quality Improvement at MTs Negeri 1 Manado}

Improving academic quality is integrated with spiritual and moral nobility or morality. As a school with Islamic characteristics, Madrasah Tsanawiyah Negeri 1 Manado in the quality improvement process must adhere to the vision, mission, and goals of the madrasa. Thus, the impact of quality improvement needs to be 
seen from the uniqueness of the madrasa as an Islamic school.

\section{Education Quality Improvement Strategy at MTs Negeri 1 Bitung}

The strategy of improving the quality of madrasa-based education and Islamic religious values is a hallmark of education implemented at Madrasah Tsanawiyah Negeri 1 Bitung, as well as the vision and mission and objectives of the madrasa. Planning to improve the quality of education in Madrasah Tsanawiyah Negeri 1 Bitung is carried out by holding a meeting with all components of the madrasa.

a) Quality Improvement Planning at MTsN 1 Bitung

Quality improvement plans that have been decided in a joint meeting with the Head of Madrasah Tsanawiyah Negeri 1 Bitung by involving stakeholders. Planning for improving the quality of madrasas is carried out by setting quality standards for madrasa education based on 8 national education standards, planning for making madrasa vision and mission planning for madrasa curriculum development, planning for teacher competency improvement, planning for providing facilities and infrastructure that support the teaching and learning process, and planning for coaching to students. The preparation of madrasa education quality standards involves all components of the madrasa. The role of the Madrasah Head in formulating educational quality standards at Madrasah Tsanawiyah Negeri 1 Bitung, as well as stakeholders who are responsible for and provide support (Supporting agency) in planning or implementing education.

b) Implementation of Quality Improvement at Bitung State Madrasah Tsanawiyah (MTs Negeri 1 Bitung).

The implementation of the quality standards of madrasa education at Madrasah Tsanawiyah Negeri 1 Bitung is carried out in accordance with the 8 National Education Standards. Madrasah Tsanawiyah Negeri 1 Bitung has determined the quality of education as a reference or guideline in carrying out educational activities. The existence of the same commitment and desire from all components of the madrasa, both committees/stakeholders as well as community leaders and teachers from the teacher council, has attempted to carry out the vision and mission of Madrasah Tsanawiyah Negeri 1 Bitung, in order to realize the quality of madrasa education, which is increasingly changing towards a dignified and meaningful education. in order to produce a generation of believers and devoted to Allah swt.

\section{c) Impact of the implementation of improving the quality of education}

The impact of implementing quality improvement strategies at Madrasah Tsanawiyah Negeri 1 Bitung can be seen from the academic achievements achieved by students. In addition, non-academic records also show achievements that provide evidence that madrasas are able to compete with other schools. The culture of quality is increasingly visible in MTs Negeri 1 Bitung. The concern and responsibility of teachers in maintaining the quality of education is the answer to the public's interest in MTs Negeri Bitung. The positive impact of the quality improvement strategy on the standards of educators and education personnel, infrastructure has an impact on increasing student motivation at MTs Negeri Bitung

\section{Strategy for Improving the Quality of Education at MTs Negeri 1 Kotamobagu}

The management concept of improving the quality of madrasa-based education in Madrasah Tsanawiyah Negeri 1 Kotamobagu is guided by the vision and mission that have been agreed with stakeholders. Improving academic quality is carried out by integrating the values of Islamic teachings, so as to create moral nobility of Islamic graduates and have good morals, and maintain the originality of madrasas as Islamic/religious institutions. Improving the quality of education is pursued in accordance with the expectations of the community/stakeholders and the government by referring to the 8 National Education Standards. MTs Negeri 1 Kotamobagu also carries out collaborative, transparent, collegial, coordinating and participatory management with all components of madrasas and stakeholders.

a) Planning to improve the quality of education in Madrasah Tsanawiyah Negeri 1 Kotamobagu.

The research findings related to planning for improving the quality of madrasa education that have been carried out are as follows: 1) planning and formulating a madrasa vision, 2) planning, making an analysis of the 
current situation and condition of madrasa education, 3) planning for teacher competency development, 4) development planning madrasa curriculum, 5) planning for the provision of infrastructure, 6) planning for fostering students to learn actively and achieve.

b) Implementation of improving the quality of education in Madrasah Tsanawiyah Negeri 1 Kotamobagu

Based on data exposure at Madrasah Tsanawiyah Negeri 1 Kotamobagu which has described research findings about the role of stakeholders in the implementation of improving the quality of madrasa education, namely: 1) Implementation of the vision and mission is supported by all parties such as educators and education staff, students, committees and stakeholders both directly or indirectly, the implementation of joint meetings provides mutual support and motivation for the implementation of the madrasa's vision and mission, 2) Stakeholder support for the implementation of the analysis and the current condition of madrasa education by providing input so that madrasas make a SWOT analysis, 3) Providing support from stakeholders towards teacher competency development, 4) Madrasah principals and stakeholders continue to strive to develop madrasah curricula, 5) Support from stakeholders both morally and materially in the procurement of educational infrastructure as needed, 6) Stakeholders participate in providing support and motivation so that madrasas pay attention to the achievements of students through intensive coaching.

c) The impact of improving the quality of education in Madrasah Tsanawiyah Negeri 1 Kotamobagu

Based on the exposure to the data described above, research findings regarding the impact of improving the quality of education in Madrasah Tsanawiyah Negeri 1 Kotamobagu were obtained, namely: 1) The impact of improving the quality of madrasa education on the final exam of madrasas with a national standard of passing 100 percent, 2) The impact of improving the quality of education madrasas on public trust are increasing by sending their children to school, 3) The impact of improving the quality of madrasa education on increasing students' faith and devotion to Allah SWT. 4) The impact of improving the quality of madrasa education on the achievement of students in Madrasah Tsanawiyah Negeri 1 Kotamobagu, 5) The impact of improving the quality of madrasa education on the value of madrasa accreditation, 6) The impact of improving the quality of madrasa education on the ability of teachers in the pedagogical field has increased.

\section{Discussion}

Strategy requires a number of stages that must be met, for example the theory of the Fred R. David (2010:128) model which suggests stages of strategy formulation that reflect the desires and goals of the organization, stages of strategy implementation that describe how to achieve goals, and strategy evaluation which is intended to evaluate and provide feedback on organizational performance. If you look at the results of this study, the strategy for improving the quality of education based on State Madrasah Tsanawiyah in Manado, Bitung and Kotamobagu has carried out two stages, namely strategy formulation and strategy implementation stages.Environmental observations and analysis were also carried out at the three research locations, this fulfilled the elements of strategic management proposed by David Hunger and Thomas L. Weelen (2003:4) that strategic management includes environmental observation, strategy formulation (strategic planning or long-term planning), strategy implementation, and evaluation and control.The quality of education in an educational institution is influenced by the institution itself in organizing quality improvement (Ismail, F. Daeng Pawero, A.M. Umar, M., 2021). So that quality improvement cannot be separated from educational programs in madrasas. Improving the quality of madrasas as schools characterized by Islam must always be integrated into the independence and spiritual attitude of all components of the madrasa. Excellent and quality madrasas must have a vision and mission, as well as goals that have been set together. In improving the quality of education, madrasas carry the mandate from the government and society, to educate students, have skills and make students believe and fear God Almighty.

In the three research locations, it appears that the head of the madrasa together with all components of 
the madrasa and stakeholders made plans through joint meetings on improving the quality of madrasas. This shows that the role of stakeholders in planning for improving the quality of madrasa education according to Sarah White's theory (1996) is at level 2, namely Instrumental Participation. At this level, it is indicated by the involvement of stakeholders in the form of program support, for example, stakeholders contribute in the form of thoughts, energy and funds.Madrasah Tsanawiyah as an educational institution with Islamic nuances must of course be able to compete with other educational institutions and even with other institutions and the world of work. For competence, madrasas must pay attention to the various needs and expectations of stakeholders. To meet the needs and expectations of madrasa stakeholders, madrasas must be able to improve the quality of services and products for their graduates. Therefore, it is very necessary for the continuity of the activity process both in the educational process and in the teaching process which is systematically carried out in building the values of knowledge, skills, and religious moral values as a characteristic of madrasas.Thus, improving the quality of the madrasa is determined by the seriousness of the madrasa itself in planning, implementing and evaluating quality improvement programs. Because according to Soetopo (2004:130) school/madrasah-based quality improvement management is a quality improvement method that relies on the school/madrasah itself, implementing a set of techniques, based on the availability of qualitative and quantitative data and empowering all components of the school/madrasah to meet the needs of participants education and society.

\section{CONCLUSION}

Based on the description above, it can be stated that the quality improvement strategy implemented is in accordance with the characteristics of the madrasa, as well as the situation analysis carried out by each madrasa. Madrasah Tsanawiyah which is the location of this research has made efforts to improve the quality of its education. Strive to realize the vision and mission of madrasas, develop curricula, improve the competence of educators and students and provide facilities and infrastructure. So it can be ascertained that the strategy of improving the quality of education in madrasas provides very positive benefits on the quality or quality of education as a whole.

\section{REFERENCES}

[1] Aziz, A.Z. 2015. Manajemen Berbasis Sekolah: Alternatif Peningkatan Mutu Pendidikan Madrasah, El Tarbawi, Jurnal Pendidikan Islam, Vol. VIII, No. 1. h. 69-92.

[2] Daft, Richard L. 2010, New Era of Management, Jakarta: Salemba Empat.

[3] David, Fred R., 2010. Strategic Management (Manajemen Strategik), Jakarta: Salemba Empat.

[4] Hunger, J.David dan Thomas L. Wheelen 2003 Manajemen Strategis, terj. Julianto Agung S. Yogyakarta: Andi.

[5] Ismail, F., AMD Pawero, M. Umar, 2021, Education Planning and Its Implications for Education Policy during the Covid-19 Pandemic, International Journal for Educational and Vocational Studies. Vol. 3, No. 2.

[6] Ismail, F., AMD Pawero, M Umar 2021, Improving Educational Quality through Optimizing the Potential of Educational Institutions in Indonesia, International Journal of Educational Research \& Social Sciences, 2 (1) p.41-46.

[7] Lengkong, S.J., Jeffry. 2019. Analysis of Strategic Planning Process at Rosa De Lima High School Tondano City, Minahasa Residence, Indonesia. Journal of Education and Practice Vol.10, No.17, 2019. (Online). (https://core.ac.uk/download/pdf/234642708.pdf), diakses 16 September 2021

[8] Mulyasa, 2002. Manajemen Berbasis Sekolah (Konsep, Strategi dan Implementasi), Bandung: Rosdakarya.

[9] Rawis, J.A.M., 2009. Analisis Tentang Organisasi Manajemen Wirausaha. Jurnal Aplikasi Manajemen Volume 7 Nomor 1 tahun 2009. (Online). (https://jurnaljam.ub.ac.id/index.php/jam/article/view/143/180), diakses 14 September 2021.

[10] Rotty, V.N.J., Senduk, J.F., Binilang, B.B., Naharia, O. 2017. Development Of Teacher Resources: Multi Case Study On Three Education Offices In North Sulawesi Province, Educational Research International, Vol.6 (4) November 2017.

[11] Rusman, 2009. Manajemen Kurikulum, Jakarta: Rajawali Press. 
[12] Soetopo, H. 2004, Pendidikan dan Pembelajaran Teori, Permasalahan dan Praktek Pendidikan, Malang: Pasca sarjana Program studi Manajemen Pendidikan.

[13] Suryana, S. 2017. Permasalahan Mutu Pendidikan dalam Perspektif Pembangunan Pendidikan, Jurnal Edukasi, Vol. 2. Nomor. 1.

[14] Sutrisno, 2005 Perberdayaan Madrasah dalam menghadapi Era Globalisasi, Jurnal pendidikan Agama islam Vol.2 No.1

[15] Tambingon, N., Henny. 2018. The Influence of Principal Leadership Style and Teacher Work Motivation on the Performance of Certified Teachers at SMA Negeri Kotamobagu, North Sulawesi, Indonesia. Journal of Education and Learning. Vol. 12, No. 3, pp. 357-365. (Online).

[16] (https://pdfs.semanticscholar.org/e96f/1b075a722269f7606f3d6b5a631fce05db3b.pdf), diakses 13 September 2021.

[17] Umar, M., F Ismail 2017, Peningkatan mutu lembaga pendidikan Islam (Tinjauan konsep mutu Edward Deming dan Joseph Juran), Jurnal Ilmiah Iqra', Vol 11, No 2 .

[18] Usman, Husaini. 2006. Manajemen Teori, Praktik dan Riset Pendidikan, Jakarta: Bumi Aksara.

[19] White, S., 1996, Depoliticising Development: The use and Abuses of participation. Development in Practice, 6 (1), 6-15 